\title{
Improving Quality Attributes of Tomato during Cold Storage by Preharvest Foliar Application of Calcium Chloride and Potassium Thiosulfate
}

\author{
Wael M. Semida ${ }^{1, a^{*}}$, Ahmed E. Emara ${ }^{1, b}$ and Mohammed A. Barakat ${ }^{1, c}$ \\ ${ }^{1}$ Hort. Department, Faculty of Agriculture, Fayoum University, Fayoum, Egypt.

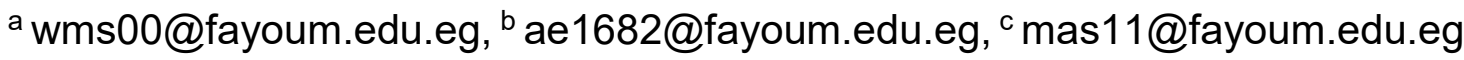 \\ ${ }^{*}$ Corresponding author
}

Keywords: calcium chloride, potassium thiosulfate, preharvest foliar application, cold storage, tomato.

\begin{abstract}
The aim of this trial was to investigate the pre-harvest foliar application of calcium chloride and potassium thiosulfate each at $0.0,0.2$ and $0.4 \%$ on some quality of tomato fruit (hybrid 65010) during cold storage. The experimental layout of cold storage experiments was a split-split-plot based on Randomized Complete Blocks design with three replications. Time of cold storage, calcium chloride and potassium thiosulfate levels were randomly distributed in the main, sub- and sub-sub plots, orderly. At the termination of cold storage, effect on tomato fruit titratable acidity, vitamin $\mathrm{C}$ and lycopene contents while, negative impact on firmness and total soluble sugars contents was obtained. At termination of cold storage, pre-harvest foliar calcium chloride at 0.2 and/or $0.4 \%$ caused increments in fruit titratable acidity, vitamin $\mathrm{C}$, total soluble sugars, lycopene and firmness contents. In addition, pre-harvest foliar potassium thiosulfate at $0.4 \%$ enhanced fruit vitamin $\mathrm{C}$, total soluble sugars, lycopene and firmness contents and also increased titratable acidity content. Generally, the interaction between cold storage $\times$ pre-harvest foliar calcium chloride or potassium thiosulfate at 0.2 and/or $0.4 \%$ increased fruit total titratable acidity, vitamin $\mathrm{C}$, total soluble sugars, lycopene and firmness contents. Also, the interaction between pre-harvest calcium chloride $\times$ potassium thiosulfate at $0.4 \%$ was distinguished and increased all studied fruit quality at the end of cold storage. The interaction treatment of cold storage $\times$ calcium chloride at $0.4 \% \times$ potassium thiosulfate at $0.4 \%$ was the best that improved fruit quality more than others.
\end{abstract}

\section{Introduction}

Tomato (Lycopersicon esculentum Mill.) is a member of the Solanaceae family, which includes potato, eggplant and pepper. Tomato crop is the most popular and a major food crop vegetable in the world [1]. In Egypt, tomato ranks the $5^{\text {th }}$ internationally in production after China, India, United States of America and Turkey [2]. Each 100 grams of ripe red tomatoes fruit almost contains of $93.8 \mathrm{~g}$ water, $3.9 \mathrm{~g}$ total carbohydrates, $0.9 \mathrm{~g}$ protein, $0.2 \mathrm{~g}$ total fat, $1.2 \mathrm{~g}$ row fibers and appropriate quantities of vitamins especially vitamin $\mathrm{C}$ and minerals in addition, some favor amounts of carotenes and lycopene [3]

Approximately half population in developing countries does not have adequate food supplies. One of the causes for food losses is tend to be highest due to postharvest system through transporting, handling, storage, processing and marketing to final delivery to the consumer [4]. Post-harvest loss of tomato fruits sometimes as high as fifty percent [5]. Reduction in postharvest food losses can be avoided to be of great significance to growers and consumers alike [6].

Postharvest qualities of tomatoes partially depend upon pre-harvest factors such as cultural practices, genetic and environmental conditions [7] [8]. Cultural practices such as nutrient, water supply and harvesting methods etc. affect quality of tomato before and after harvest [9] [10], [11], [12] proved that, calcium chloride and potassium thiosulfate have major and important roles on plant behavior, storability and quality attributes of tomato 
Accordingly, the present investigation was proposed to study the effects of spraying canopy of tomato plant with calcium chloride and potassium thiosulfate on subsequent effect on fruit quality attributes during cold storage.

\section{Materials and Methods}

Two similar filed experiments were achieved during the two fall seasons of 2014 and 2015, in a private farm located at Senoras, Fayoum Governorate, Egypt. To identify some physical and chemical properties of the experimental site, soil samples to $25 \mathrm{~cm}$ depth, preceding the initiation of each field experiment, were collected. Soil samples were analyzed at Soil Testing Laboratory, College of Agriculture, Fayoum University, according to the standard published procedures [13]. Results of the soil analysis are given in Table 1.

Table 1. Some important physical and chemical properties of the experimental site in 2014 and 2015 seasons

\begin{tabular}{lcc}
\hline & \multicolumn{1}{c}{ Value } & \\
\cline { 2 - 3 } Physical characteristics & $\mathbf{2 0 1 4}$ & $\mathbf{2 0 1 5}$ \\
\hline Silt (\%) & 46.8 & 46.2 \\
Clay (\%) & 43.5 & 44.1 \\
Fine sand (\%) & 4.1 & 3.9 \\
Coarse sand (\%) & 5.6 & 5.8 \\
Soil texture & Silty Clay & Silty Clay \\
\hline Chemical characteristics & & \\
\hline pH [at a soil: water (w/v) ratio of 1:2.5] & 7.587 & 7.635 \\
ECe (ds/m; soil - paste extract) & 2.35 & 2.36 \\
Organic matter (\%) & 1.38 & 1.48 \\
Nitrate (NO) (mg/kg) & 253 & 261 \\
Available (P) (mg/kg) & 50.1 & 48.8 \\
Available (K) (mg/kg) & 364 & 383 \\
Ca (mg/100g soil) & 14.1 & 12.06 \\
Mg (mg/100g soil) & 7.22 & 4.59 \\
CaCO $\mathbf{3}$ (\%) & 3 & 4.4 \\
\hline
\end{tabular}

Tomato seed hybrid 65010 were sown in speedling trays on July $1^{\text {st }}$ and $9^{\text {th }}$ in 2014 of 2015 , orderly and placed under net house conditions. After 30 days, tomato transplants were transplanted on rows at in-row spacing of $50 \mathrm{~cm}$. Aqueous solution of each calcium chloride and potassium thiosulfate with concentrations $0,0.2$ and $0.4 \%$ were sprayed to run off after 40,70 and 100 days transplanting. Canopy of tomato plants were first sprayed with aqueous solution of calcium chloride then, after getting dry, with aqueous solution of potassium thiosulfate. All other agro-management practices such as nutrition, cultivation, irrigation and pests control were performed whenever it was necessary and as recommended in the commercial production of tomato. After 115 days transplanting, tomato fruits of pink maturity stage were harvested. A collective sample of tomato fruits treatment ${ }^{-1}$ was mixed. There were nine tomato fruit samples in total. Each collective sample comprising 54 tomato fruits and was divided into two equal batches of $27^{\text {th }}$, packed in cardboard boxes and placed in refrigerator at temperature at $10 \pm 2{ }^{\circ} \mathrm{C}$ and relative humidity of $90 \%$. The $1^{\text {st }}$ and $2^{\text {nd }}$ batches were allocated to determine fruit quality at the beginning $\left(\begin{array}{ll}0 & \text { day }\end{array}\right)$ and termination (28 days) of cold storage, respectively. The experimental layout of cold storage was a split-split plot based on Randomly Complete Blocks Design with three replications. Periods of storage was allocated to the main plots whereas, pre-harvest foliar applications of calcium chloride and potassium thiosulfate were randomly assigned to the sub- and sub-sub plots, respectively. 


\section{Data Recorded}

At the beginning and termination of cold storage, the following determinations were assayed:

1. Fruit titratable acidity content; determined by titration with $0.01 \mathrm{~N} \mathrm{NaOH}$ as outlined by [14]. The titratable acidity content was expressed as a percent.

2. Fruit ascorbic acid (Vitamin C) content; assayed using a method of titration with 2, 6 dichlorophenol indophenol as outlined by [14]. Fruits ascorbic acid content was expressed as $\mathrm{mg} \mathrm{ml}^{-1}$ juice.

3. Fruit total soluble sugars (TSS) content; measured by hand held brix refractometer model (RHB 0-32) in clear tomato fruits juice. Fruits total soluble solids was expressed as a percent.

4. Fruit Lycopene content; Fruit lycopene content was extracted using a mixture of hexane, acetone and ethanol (2:1:1), 0.05\% (w/v) butylated hydroxyl toluene (BHT) and photometrical measured by modified method of [15] at wave length of $503 \mathrm{~nm}$. The lycopene content was expressed as $\mathrm{mg} \mathrm{g}^{-1}$ fruit.

5. Fruit firmness; determined by fruit firmness tester with a plunger $6 \mathrm{~mm}$ diameter Model 53200 fruit penetrometer, range till $13 \mathrm{~kg}$ (T. R. Turoni srl, Via Copernico 26, 47122 Forlì, Italy). Fruits firmness was expressed in $\mathrm{kg} \mathrm{cm}^{-2}$.

\section{Statistical Analysis}

Data subjected to analysis of Variance according to the design used and Revised Least Significant test introduced by [16] was utilized to verify difference among the experimental treatments.

\section{Results and Discussion}

\section{Fruit titratable acidity content}

Table 2 shows the main and interaction impacts of cold storage, pre-harvest foliar of calcium chloride and potassium thiosulfate on fruit titratable acidity content of tomato, during cold storage of 2014 and 2015 seasons.

Fruit titratable acidity content was, significantly, higher at the termination (28 day) than the beginning ( 0 day) in cold storage, in both season. Pre-harvest foliar calcium chloride at $0.2 \%$ was, significantly, higher in fruit titratable acidity content than pre-harvest foliar calcium chloride at $0.4 \%$ and control, in $1^{\text {st }}$ season while, fruit titratable acidity content was, significantly, higher with untreated control than the pre-harvest foliar of calcium chloride either at 0.2 or $0.4 \%$, in $2^{\text {nd }}$ season. Pre-harvest foliar application of potassium thiosulfate either at 0.2 or $0.4 \%$ was, significantly, increased in total fruit acidity content relative to the untreated treatment, in $1^{\text {st }}$ season, whereas, in $2^{\text {nd }}$ season vice versa was true.

The $1^{\text {st }}$ order interaction effect between any two studied factors on fruit titratable acidity content during cold storage was significant, in both seasons.

The interaction between cold storage at termination $\times$ foliar calcium chloride at $0.4 \%$ or $0.2 \%$ was, significantly, higher than other combined treatments in fruit titratable acidity content, in $1^{\text {st }}$ and $2^{\text {nd }}$ seasons, orderly. Regarding the interaction between the termination of cold storage $\times$ foliar potassium thiosulfate at 0.2 or $0.4 \%$ was, statistically, higher than other combined treatments in fruit titratable acidity content, in $1^{\text {st }}$ season while, the interaction of termination in cold storage $\times$ foliar the untreated control was, statistically, higher than other combined treatments in fruit titratable acidity content, in $2^{\text {nd }}$ season. Comparison the mean values of interaction between pre-harvest foliar calcium chloride $\times$ potassium thiosulfate showed that, the combined treatment of calcium chloride at $0.4 \%+$ potassium thiosulfate at $0.2 \%$ was, significantly, the highest value in fruit titratable acidity content, in $1^{\text {st }}$ season nevertheless, the combined treatment of calcium chloride at $0.2 \%+$ potassium thiosulfate at $0.0 \%$ was, significantly, highest value in fruit titratable acidity content, in $2^{\text {nd }}$ season.

The effect of $2^{\text {nd }}$ order interaction among the three studied factors on fruit titratable acidity content was significant, in the two experimental seasons. At the termination of cold storage, pre- 
harvest foliar application of calcium chloride at $0.4 \%+$ pre-harvest foliar potassium thiosulfate at $0.2 \%$ and pre-harvest foliar application of calcium chloride at $0.0 \%+$ pre-harvest foliar potassium thiosulfate at $0.4 \%$ were, significantly, the highest mean value in fruit titratable acidity content, in $1^{\text {st }}$ and $2^{\text {nd }}$ season.

The enhancing effect of fruit titratable acidity content at the termination than the beginning of cold storage was expected. This result may be attributed to a sufficient time of cold storage to enable the effectiveness of retarded metabolic process which account fruit titratable acidity content to be higher.

The retarding effect of pre-harvest foliar application of calcium chloride either at 0.2 or $0.4 \%$ on fruit titratable acidity content, in $2^{\text {nd }}$ season can be explained on the basis that, calcium chloride an ethylene inhibitor [17] and ethylene plays an active role in the tomatoes ripening process [18] and ripening is also associated with the conversion of starch and acids to sugars. This conclusion was supported by [19] who mentioned that, treating tomato fruits with calcium chloride, irrespective of the concentration used, significantly decreased titratable acidity content than the control. Similar conclusion was introduced by [20].

Pre-harvest foliar application of potassium thiosulfate reflected conflicting results on fruit titratable acidity between the two seasons. In 2014 season, pre-harvest foliar application of potassium thiosulfate at 0.2 or $0.4 \%$, significantly, augmented fruit titratable acidity content whereas, in 2015 season, the reversal was true compared to untreated control. As an average of the two seasons, preharvest foliar application of potassium thiosulfate at 0.2 and $0.4 \%$ compared to control averaged + 2.06 and $-2.86 \%$, orderly. As an average of the two seasons, net pre-harvest foliar application of potassium thiosulfate on fruit titratable acidity content was reduced by $0.80 \%$. Un-likely, [21] displayed that, potassium in both soil $\left(3.3\right.$ and $\left.6.6 \mathrm{mmol} \mathrm{kg}^{-1}\right)$ and foliar forms $(4.5$ and $9 \mathrm{mM})$ caused a significant increase in fruit tomato titratable acidity of fruit content compared to respective controls in all genotypes.

Table 2. Main and interaction effects of time in cold storage, pre-harvest foliar application of calcium chloride and potassium thiosulfate on fruit titratable acidity content (\%) during 2014 and 2015 seasons

\begin{tabular}{|c|c|c|c|c|c|c|c|c|c|}
\hline \multirow{3}{*}{ Time } & \multirow{3}{*}{$\begin{array}{l}\text { Seasons } \\
\text { Calcium } \\
\text { chloride } \\
(\%)\end{array}$} & \multicolumn{3}{|c|}{2014} & \multirow{3}{*}{ Mean } & \multicolumn{3}{|c|}{2015} & \multirow{3}{*}{ Mean } \\
\hline & & \multicolumn{3}{|c|}{$\begin{array}{c}\text { Potassium Thiosulfate } \\
(\%)\end{array}$} & & \multicolumn{3}{|c|}{$\begin{array}{c}\text { Potassium Thiosulfate } \\
(\%)\end{array}$} & \\
\hline & & 0.0 & 0.2 & 0.4 & & 0.0 & 0.2 & 0.4 & \\
\hline \multirow{3}{*}{$\begin{array}{c}0 \\
\text { Day }\end{array}$} & 0.0 & $0.3413^{\mathrm{i}^{*}}$ & $0.4523^{\mathrm{h}}$ & $0.2901^{j}$ & $0.3612^{\mathrm{d}}$ & $0.499^{\mathrm{e}-\mathrm{g}}$ & $0.5291^{\mathrm{e}}$ & $0.4395^{\mathrm{I}}$ & $0.4892^{\mathrm{d}}$ \\
\hline & 0.2 & $0.5632^{g}$ & $0.4437^{\mathrm{h}}$ & $0.4309^{\mathrm{h}}$ & $0.4793^{\mathrm{c}}$ & $0.482^{\mathrm{f}-\mathrm{h}}$ & $0.4608^{\mathrm{hi}}$ & $0.5163^{\mathrm{e}}$ & $0.4864^{d}$ \\
\hline & 0.4 & $0.3456^{\mathrm{i}}$ & $0.3157^{\mathrm{ij}}$ & $0.3029^{j}$ & $0.3214^{\mathrm{e}}$ & $0.4480^{\mathrm{hi}}$ & $0.4693^{\mathrm{g}-\mathrm{i}}$ & $0.3456^{\mathrm{j}}$ & $0.4210^{\mathrm{e}}$ \\
\hline \multirow{3}{*}{$\begin{array}{c}28 \\
\text { Day }\end{array}$} & 0.0 & $0.7936^{\mathrm{c}}$ & $0.7936^{\mathrm{c}}$ & $0.8021^{\mathrm{c}}$ & $0.7964^{b}$ & $0.7936^{c}$ & $0.7936^{c}$ & $0.9088^{\mathrm{a}}$ & $0.8320^{\mathrm{a}}$ \\
\hline & 0.2 & $0.6315^{\mathrm{f}}$ & $0.7424^{\mathrm{d}}$ & $0.8107^{\mathrm{bc}}$ & $0.7282^{c}$ & $0.9387^{\mathrm{a}}$ & $0.7851^{\mathrm{c}}$ & $0.5077^{\mathrm{ef}}$ & $0.7438^{c}$ \\
\hline & 0.4 & $0.6827^{\mathrm{e}}$ & $0.9301^{\mathrm{a}}$ & $0.8491^{\mathrm{b}}$ & $0.8206^{\mathrm{a}}$ & $0.7808^{c}$ & $0.6912^{d}$ & $0.8491^{\mathrm{b}}$ & $0.7737^{\mathrm{b}}$ \\
\hline 0 day & & $0.4167^{\mathrm{c}}$ & $0.4039^{d}$ & $0.3413^{\mathrm{e}}$ & $0.3873^{\mathrm{B}}$ & $0.4764^{\mathrm{c}}$ & $0.4864^{\mathrm{c}}$ & $0.4338^{\mathrm{e}}$ & $0.4655^{\mathrm{B}}$ \\
\hline \multirow[t]{4}{*}{$\begin{array}{l}28 \\
\text { day }\end{array}$} & & & $0.8220 \mathrm{a}$ & $0.8206^{\mathrm{a}}$ & $0.781^{\mathrm{A}}$ & $0.8377^{\mathrm{a}}$ & $0.7566^{\mathrm{b}}$ & $0.7552^{\mathrm{b}}$ & $0.7832^{\mathrm{A}}$ \\
\hline & 0.0 & $0.5675^{\mathrm{cd}}$ & $0.6229^{\mathrm{a}}$ & $0.5461^{\mathrm{d}}$ & $0.5788^{\mathrm{B}}$ & $0.6464^{\mathrm{cd}}$ & $0.6613^{b} c$ & $0.6741 \mathrm{~b}$ & $0.6606^{\mathrm{A}}$ \\
\hline & 0.2 & $0.5973^{b}$ & $0.5931^{\mathrm{b}}$ & $0.6208^{\mathrm{a}}$ & $0.6037^{\mathrm{A}}$ & $0.7104^{\mathrm{a}}$ & $0.6229^{\mathrm{de}}$ & $0.5120^{\mathrm{g}}$ & $0.6151^{\mathrm{B}}$ \\
\hline & 0.4 & $0.5141^{\mathrm{e}}$ & $0.6229^{\mathrm{a}}$ & $0.5760^{\mathrm{c}}$ & $0.5710^{\mathrm{B}}$ & $0.6144^{\mathrm{e}}$ & $0.5803^{\mathrm{f}}$ & $0.5973^{\text {ef }}$ & $0.5973^{\mathrm{B}}$ \\
\hline Mean & & $0.5596^{\mathrm{C}}$ & $0.6130^{\mathrm{A}}$ & $0.5810^{\mathrm{B}}$ & & $0.6571^{\mathrm{A}}$ & $0.6215^{\mathrm{B}}$ & $0.5945^{\mathrm{C}}$ & \\
\hline
\end{tabular}

${ }^{*}$ Values marked with the same letter(s) within the main and interaction effects are statically similar using Revised LSD. Test at probability $=0.05$. Uppercase letter(s) indicate differences between main effects whilst, lowercase letter(s) refer to differences between interaction. 


\section{Fruit vitamin $\mathbf{C}$ content}

Table 3 shows the main and interaction influence of period of cold storage, pre-harvest foliar of calcium chloride and potassium thiosulfate on fruit vitamin $\mathrm{C}$ content of tomato, during both experimental seasons.

Fruit vitamin $\mathrm{C}$ content in fruit was, intrinsically, higher at the termination than beginning during cold storage, in the two inquest seasons. Pre-harvest foliar calcium chloride at $0.2 \%$ was, significantly, pioneer in fruit vitamin $\mathrm{C}$ content compared to the control treatment, in both seasons. Increasing the exogenous application of potassium thiosulfate from 0 to 0.2 and further to $0.4 \%$ accompanied with, significant, corresponding increases in fruit vitamin $\mathrm{C}$ content, in both years.

The $1^{\text {st }}$ order interaction between any two studied factors was, significant, in both seasons. Concerning the effect of $1^{\text {st }}$ order interaction between the terminations of cold storage $\times$ pre-harvest foliar calcium chloride at $0.2 \%$ was, statistically, higher in vitamin $\mathrm{C}$ than the other combined treatments, in both seasons. As for the effect of interaction between the terminations of cold storage $\times$ pre-harvest foliar calcium chloride at $0.4 \%$ was, statistically, higher in vitamin $C$ than the other combined treatments, in both seasons. Regarding the interaction between pre-harvest foliar calcium chloride at $0.4 \% \times$ pre-harvest foliar potassium thiosulfate at $0.4 \%$ was, significantly, distinguished in vitamin $\mathrm{C}$ compared other combined treatments, in both years.

The effect of $2^{\text {nd }}$ order interaction among the three studied factors on fruit vitamin $C$ content was significant, in both years. At the termination of cold storage, pre-harvest foliar either calcium chloride or potassium thiosulfate at $0.4 \%$ were, significantly, higher than other combined treatments in fruit vitamin $\mathrm{C}$ content, in two seasons.

The beneficial effect on fruit vitamin $\mathrm{C}$ content at the termination than the beginning in cold storage might be owe to during cold storage, fruit vitamin $\mathrm{C}$ content increased first with the ripening stage from light pink to red stage of ripening [10]. As an average of the two seasons, fruit vitamin $\mathrm{C}$ content increased at the termination over the beginning of cold storage by $66.02 \%$ (Table 2 ).

The desirable effect of pre-harvest foliar calcium chloride on fruit vitamin $\mathrm{C}$ content during cold storage can be explained on the basis that, treated plants with calcium chloride showed slow metabolic activities therefore, untreated plants respiration rate and ethylene production were at higher rate and ascorbic acid decreased rapidly as compared to calcium treated plants. Several investigators coincided our results as [10], [23] who emphasized that, foliar application of tomato plants with calcium chloride at 10 and $15 \mathrm{mM}$, significantly, resulted in higher fruit vitamin C content compared to the check treatment.

The promoting response on fruit vitamin $\mathrm{C}$ content due to pre-harvest foliar application of potassium thiosulfate was in accordance with [25] who displayed that, potassium addition reflected a positive effect on the vitamin $\mathrm{C}$ content of tomato fruits. Also, reported that, fruit vitamin $\mathrm{C}$ content increased with $\mathrm{K}$ application regardless of the sources. On the same side, foliar treatments of potassium; $0.5,0.6$ and $0.7 \%$ maximally improved ascorbic acid contents of both tomato cultivars [27].

The enhancing effect at the termination of cold storage due to pre-harvest foliar application of calcium chloride at $0.2 \%$, potassium thiosulfate at $0.4 \%$ and both at $0.4 \%$ on fruit vitamin $\mathrm{C}$ content might be attributed to the contribution of pre-harvest foliar application of calcium chloride and/or potassium thiosulfate to retard the metabolic process during the cold storage with an eventual result of increasing fruit vitamin $\mathrm{C}$ content. 
Table 3. Main and interaction effects of time in cold storage, pre-harvest foliar application of calcium chloride and potassium thiosulfate on fruit vitamin $\mathrm{C}\left(\mathrm{mg} \mathrm{ml}^{-1}\right.$ juice) content during 2014 and 2015 seasons

\begin{tabular}{|c|c|c|c|c|c|c|c|c|c|}
\hline \multirow{3}{*}{ Time } & \multirow{3}{*}{$\begin{array}{c}\text { Seasons } \\
\text { Calcium } \\
\text { chloride } \\
(\%)\end{array}$} & \multicolumn{3}{|c|}{2014} & \multicolumn{4}{|c|}{2015} & \multirow{3}{*}{ Mean } \\
\hline & & \multicolumn{3}{|c|}{$\begin{array}{c}\text { Potassium Thiosulfate } \\
\text { (\%) }\end{array}$} & \multirow[t]{2}{*}{ Mean } & \multicolumn{3}{|c|}{$\begin{array}{c}\text { Potassium Thiosulfate } \\
\text { (\%) }\end{array}$} & \\
\hline & & 0.0 & 0.2 & 0.4 & & 0.0 & 0.2 & 0.4 & \\
\hline \multirow{2}{*}{ 0 } & 0.0 & $0.2222^{\mathrm{h} *}$ & $0.2307^{\mathrm{h}}$ & $0.2159^{\mathrm{h}}$ & $0.2229^{\mathrm{d}}$ & $0.2118^{1}$ & $0.3431^{\mathrm{d}}$ & $0.2755^{\mathrm{fg}}$ & $0.2787^{\mathrm{c}}$ \\
\hline & 0.2 & $0.1672^{\mathrm{J}}$ & $0.2476^{\mathrm{g}}$ & $0.1947^{\mathrm{I}}$ & $0.2032^{\mathrm{e}}$ & $0.2216^{\mathrm{kl}}$ & $0.2637^{\mathrm{gh}}$ & $0.2284^{\mathrm{ef}}$ & $0.2379^{\mathrm{d}}$ \\
\hline Day & 0.4 & $0.1016^{1}$ & $0.1418^{\mathrm{k}}$ & $0.1418^{\mathrm{k}}$ & $0.1284^{\mathrm{f}}$ & $0.2598^{\mathrm{hi}}$ & $0.3412^{d}$ & $0.2324^{\mathrm{jk}}$ & $0.2768^{\mathrm{c}}$ \\
\hline \multirow{2}{*}{28} & 0.0 & $0.2703^{f}$ & $0.2162^{\mathrm{h}}$ & $0.2919^{\mathrm{e}}$ & $0.2595^{\mathrm{c}}$ & $0.2467^{\mathrm{ij}}$ & $0.2233^{\mathrm{kl}}$ & $0.3680^{c}$ & $0.2793^{\mathrm{c}}$ \\
\hline & 0.2 & $0.4468^{\mathrm{b}}$ & $0.3910^{\mathrm{d}}$ & $0.4523^{\mathrm{b}}$ & $0.4300^{\mathrm{a}}$ & $0.4800^{\mathrm{b}}$ & $0.4707^{\mathrm{b}}$ & $0.2973^{\mathrm{e}}$ & $0.4160^{\mathrm{a}}$ \\
\hline Day & 0.4 & $0.2757^{f}$ & $0.4180^{\mathrm{c}}$ & $0.5613^{\mathrm{a}}$ & $0.4183^{b}$ & 0.2853 ef & $0.2107^{1}$ & $0.5613^{a}$ & $0.3524^{b}$ \\
\hline 0 day & & $0.1637^{\mathrm{f}}$ & $0.2067^{\mathrm{d}}$ & $0.1841^{\mathrm{e}}$ & $0.1848^{\mathrm{B}}$ & $0.2310^{\mathrm{f}}$ & $0.3160^{\mathrm{c}}$ & $0.2454^{\mathrm{e}}$ & $0.2642^{\mathrm{B}}$ \\
\hline \multirow[t]{4}{*}{28 day } & & $0.3309^{\mathrm{c}}$ & $0.3417^{\mathrm{b}}$ & $0.4352^{\mathrm{a}}$ & $0.3693^{\mathrm{A}}$ & $0.3373^{b}$ & $0.3016^{\mathrm{d}}$ & $0.4089^{\mathrm{a}}$ & $0.3493^{\mathrm{A}}$ \\
\hline & 0.0 & $0.2462^{\mathrm{e}}$ & $0.2235^{\mathrm{f}}$ & $0.2539^{\mathrm{e}}$ & $0.2412^{\mathrm{C}}$ & $0.2292^{\mathrm{g}}$ & $0.2832^{\mathrm{e}}$ & $0.3217^{\mathrm{d}}$ & $0.2781^{\mathrm{C}}$ \\
\hline & 0.2 & $0.3070^{\mathrm{c}}$ & $0.3193^{b}$ & $0.3235^{\mathrm{b}}$ & $0.3166^{\mathrm{A}}$ & $0.3508^{c}$ & $0.3672^{b}$ & $0.2629^{f}$ & $0.3270^{\mathrm{A}}$ \\
\hline & 0.4 & $0.1886^{\mathrm{g}}$ & $0.2799^{d}$ & $0.3516^{\mathrm{a}}$ & $0.2734^{\mathrm{B}}$ & $0.2726^{\mathrm{f}}$ & $0.2759^{\text {ef }}$ & $0.3968^{a}$ & $0.3151^{\mathrm{B}}$ \\
\hline Mean & & $0.2473^{\mathrm{C}}$ & $0.2742^{\mathrm{B}}$ & $0.3096^{\mathrm{A}}$ & & $0.2842^{\mathrm{C}}$ & $0.3088^{\mathrm{B}}$ & $0.3272^{\mathrm{A}}$ & \\
\hline
\end{tabular}

\footnotetext{
*Values marked with the same letter(s) within the main and interaction effects are statically similar using Revised LSD. Test at probability $=0.05$. Uppercase letter(s) indicate differences between main effects whilst, lowercase letter(s) refer to differences between interaction.
}

\section{Fruit total soluble sugars content}

Comparisons listed in Table 4 show the main and different order interactions effects of three studied factors under study on total soluble sugars, through both experimental seasons.

The response of fruit total soluble sugars content to period of cold storage was varied, significantly, between the two seasons. In 2014 season, the mean value of fruit total soluble sugars content was, significantly, increased at end than beginning of cold storage. In 2015 season, vice versa was really true. Pre-harvest foliar application of calcium chloride at $0.4 \%$, statistically, produced the highest content of fruit total soluble sugars, in both seasons. Pre-harvest foliar potassium thiosulfate at $0.4 \%$, statistically, gave higher mean value in fruit total soluble sugars content than foliar potassium thiosulfate at $0.2 \%$ and standard treatment, in both seasons.

Influence of $1^{\text {st }}$ order interaction between any two studied factors on fruit total soluble sugars content was significant, in both seasons. Concerning the effect of interaction between termination of cold storage $\times$ pre-harvest foliar calcium chloride or potassium thiosulfate at $0.4 \%$ was, statistically, higher in fruit total soluble sugars content than other combined treatments, in both seasons. Regarding the impact of interaction between pre-harvest foliar calcium chloride at $0.4 \% \times$ potassium thiosulfate at 0.2 and/or $0.4 \%$ was, truly, higher in fruit total soluble sugars content than other combined treatments, in both seasons.

Comparisons among the $2^{\text {nd }}$ interaction illustrated that, the combined treatment of termination in cold storage + calcium chloride at $0.4 \%+$ potassium thiosulfate at $0.4 \%$ recoded, significantly, highest mean value in fruit total soluble sugars content, in both seasons. 
The promoting effect of pre-harvest calcium chloride at $0.4 \%$ on fruit total soluble sugars content during cold storage probably due to increase the respiration and metabolic activity, hence increment the ripening process. Results of [24] ; [19] were in accordance with our results. On the other extreme, several investigators approach to the conclusion that treated plants with calcium chloride decreased fruit total soluble sugars content [28]; [22].

Result of enhancing treated- tomato plants with potassium thiosulfate at $0.4 \%$ on fruit total soluble sugars content during cold storage was in close accordance with those of [29] ; [24]. [30] displayed that, the application of foliar potassium via Nutri-Vant-PeaK is beneficial for tomato fruits $\mathrm{cv}$. Durinta after storage at $12 \mathrm{C}^{\circ}$ for 12 days as, significantly, increased fruit glucose and total soluble solid contents relative to the untreated fruit.

The $1^{\text {st }}$ interaction effect between time in cold storage and either pre-harvest foliar application of calcium chloride or potassium thiosulfate each at $0.4 \%$, during the termination of cold storage, recorded the highest mean value of fruit total soluble sugars content. Accordingly, at the termination in cold storage, the $1^{\text {st }}$ interaction between pre-harvest foliar applications of calcium chloride together with potassium thiosulfate each at $0.4 \%$ attained the highest mean value of fruit total soluble sugars content.

The effect of $2^{\text {nd }}$ order interaction among three studied factors under study on fruit lycopene content was, significant, in both years. Comparisons among mean value of $2^{\text {nd }}$ interactions showed that, the combined treatment at termination of cold storage + calcium chloride at $0.4 \%+$ potassium thiosulfate at $0.4 \%$ was, significantly, higher mean value than values of other combined treatments, in both years.

The stimulative influence on fruit lycopene content at the termination than the beginning of cold storage may be arise due to degradation of chlorophyll and increase the synthesis of lycopene which comprising $80-90 \%$ of carotenoids [31] [32]. Similar result has been reported by [23].

The positive effect of pre-harvest foliar application of calcium chloride on fruit lycopene content at termination than beginning of cold storage were in parallel to the results obtained by [10], [22] and [24] who elucidated that, foliar application of tomato plants with 10 and $15 \mathrm{mM} \mathrm{Ca}$, significantly, resulted in higher fruit lycopene content compared to the check treatment.

The synergistic effect of pre-harvest foliar application of potassium thiosulfate on fruit lycopene content during cold storage was in accordance with [21] and [27] who mentioned that, exogenous application of potassium in tomato plants cv. Nagina at $0.6 \%$ and $\mathrm{cv}$. Roma at $0.7 \%$ reflected maximum fruit lycopene content. On the other extreme, fruits lycopene content of tomato did not show any appropriate effect whether exogenous application of potassium was at 6 or $8 \mathrm{~m} \mathrm{M}$ compared to control treatment [24].

The improving effect of $1^{\text {st }}$ order interaction between time of cold storage and foliar treated plants with calcium chloride or potassium thiosulfate at $0.4 \%$ on fruit lycopene content can be discussed on the basis that, As an average of the two seasons, at termination of cold storage; exogenous application of tomato plants at $0.4 \%$ calcium chloride surpassed over $0.2 \%$ and untreated control by 4.42 and $9.82 \%$ and pre-harvest foliar application of potassium thiosulfate at $0.4 \%$ augmented over $0.2 \%$ and control by 11.29 and $19.24 \%$, respectively.

The enhancing effect of 2 nd order interaction among the three studied factors on fruit lycopene content can be discussed on the current results; as an averaged of the two seasons, the combined treatment of termination of cold storage + pre-harvest foliar calcium chloride at $0.4 \%+$ potassium thiosulfate at $0.4 \%$ achieved the highest fruit lycopene content compared to untreated treatment by $29.80 \%$. 
Table 4. Main and interaction effects of time in cold storage, pre-harvest foliar application of calcium chloride and potassium thiosulfate on fruit total soluble sugars (\%) content during 2014 and 2015 seasons

\begin{tabular}{|c|c|c|c|c|c|c|c|c|c|}
\hline \multirow{3}{*}{ Time } & \multirow{3}{*}{$\begin{array}{c}\text { Seasons } \\
\text { Calcium } \\
\text { chloride } \\
(\%)\end{array}$} & \multicolumn{3}{|c|}{2014} & \multirow{3}{*}{ Mean } & \multicolumn{3}{|c|}{2015} & \multirow{3}{*}{ Mean } \\
\hline & & \multicolumn{3}{|c|}{$\begin{array}{c}\text { Potassium Thiosulfate } \\
(\%)\end{array}$} & & \multicolumn{3}{|c|}{$\begin{array}{c}\text { Potassium Thiosulfate } \\
(\%)\end{array}$} & \\
\hline & & 0.0 & 0.2 & 0.4 & & 0.0 & 0.2 & 0.4 & \\
\hline \multirow{3}{*}{$\begin{array}{c}0 \\
\text { Day }\end{array}$} & 0.0 & $3.167^{\text {be } *}$ & $3.033^{\mathrm{c}-\mathrm{e}}$ & $3.333^{\mathrm{b}-\mathrm{e}}$ & $3.178^{\mathrm{b}-\mathrm{d}}$ & $5.367^{\mathrm{a}-\mathrm{c}}$ & $5.167^{\mathrm{a}-\mathrm{c}}$ & $5.23^{\mathrm{a}-\mathrm{c}}$ & $5.256^{\mathrm{bc}}$ \\
\hline & 0.2 & $3.100^{\mathrm{b}-\mathrm{e}}$ & $3.400^{\mathrm{b}-\mathrm{d}}$ & $3.100^{\mathrm{b}-\mathrm{e}}$ & $2.889^{\mathrm{d}}$ & $5.033^{\mathrm{bc}}$ & $4.933^{c}$ & $5.200^{\mathrm{a}-\mathrm{c}}$ & $5.056^{\mathrm{c}}$ \\
\hline & 0.4 & $2.800^{\mathrm{e}}$ & $2.967 \mathrm{de}$ & $2.900 \mathrm{de}$ & $3.200^{b c}$ & $5.800^{a b}$ & $5.933^{\mathrm{a}}$ & $5.367^{\mathrm{a}-\mathrm{c}}$ & $5.700^{a b}$ \\
\hline \multirow{3}{*}{$\begin{array}{c}28 \\
\text { Day }\end{array}$} & 0.0 & $3.033^{\mathrm{c}-\mathrm{e}}$ & $2.833^{\mathrm{e}}$ & $3.100^{\mathrm{b}-\mathrm{e}}$ & $2.989^{\text {cd }}$ & $3.000^{\mathrm{d}}$ & $2.833^{\mathrm{d}}$ & $5.233^{\mathrm{a}-\mathrm{c}}$ & $3.689^{\mathrm{d}}$ \\
\hline & 0.2 & $3.600^{b}$ & $3.000^{\mathrm{de}}$ & $3.500^{b c}$ & $3.367^{b}$ & $5.800^{\mathrm{ab}}$ & $5.733^{\mathrm{a}-\mathrm{c}}$ & $5.700^{\mathrm{a}-\mathrm{c}}$ & $5.556^{\mathrm{ab}}$ \\
\hline & & $3.400^{\mathrm{b}-\mathrm{d}}$ & $3.567 \mathrm{bc}$ & $5.933^{\mathrm{a}}$ & $4.300^{\mathrm{a}}$ & $5.167^{\mathrm{a}-\mathrm{c}}$ & $5.567^{\mathrm{a}-\mathrm{c}}$ & $5.933^{\text {a }}$ & $5.744^{\mathrm{a}}$ \\
\hline 0 day & & $3.022 \mathrm{bc}$ & $3.133^{b c}$ & $3.111^{b c}$ & $3.089^{\mathrm{B}}$ & $5.400^{\mathrm{a}}$ & $5.344^{\mathrm{a}}$ & $5.267^{\mathrm{a}}$ & $5.337^{\mathrm{A}}$ \\
\hline \multirow[t]{4}{*}{28 day } & & $3.344^{\mathrm{b}}$ & $3.133^{b c}$ & $4.178^{\mathrm{a}}$ & $3.552^{\mathrm{A}}$ & $4.656^{\mathrm{b}}$ & $4.711^{b}$ & $5.622^{\mathrm{a}}$ & $4.996^{\mathrm{B}}$ \\
\hline & 0.0 & $3.100^{b c}$ & $2.933^{c}$ & $3.217 \mathrm{bc}$ & $3.083^{\text {B }}$ & $4.183^{b}$ & $4.000^{b}$ & $5.233^{\mathrm{a}}$ & $4.472^{\mathrm{B}}$ \\
\hline & 0.2 & $3.350^{\mathrm{b}}$ & $3.200^{b c}$ & $3.300^{b c}$ & $3.283^{\text {В }}$ & $5.417^{\mathrm{a}}$ & $5.333^{\mathrm{a}}$ & $5.450^{\mathrm{a}}$ & $5.400^{\mathrm{A}}$ \\
\hline & 0.4 & $3.100^{b c}$ & $3.267^{b c}$ & $4.417^{\mathrm{a}}$ & $3.594^{\mathrm{A}}$ & $5.483^{\mathrm{a}}$ & $5.750^{\mathrm{a}}$ & $5.650^{\mathrm{a}}$ & $5.628^{\mathrm{A}}$ \\
\hline Mean & & $3.183^{\mathrm{B}}$ & $3.133^{\mathrm{B}}$ & $3.644^{\mathrm{A}}$ & & $5.028^{\mathrm{B}}$ & $5.028^{\text {B }}$ & $5.444^{\mathrm{A}}$ & \\
\hline
\end{tabular}

${ }^{*}$ Values marked with the same letter(s) within the main and interaction effects are statically similar using Revised LSD. Test at probability $=0.05$. Uppercase letter(s) indicate differences between main effects whilst, lowercase letter(s) refer to differences between interaction.

\section{Fruit lycopene content}

The results of main and different interactions as affected by three factors under study during 2014 and 2015 seasons are presented in Table 5.

Fruit lycopene content was, significantly, higher at the termination than beginning of cold storage, in both seasons. Increasing the pre-harvest foliar application of calcium chloride or potassium thiosulfate from 0 to 0.2 and further to $0.4 \%$ accompanied by gradually and significantly increased on fruit lycopene content, in both years.

The $1^{\text {st }}$ order interaction between any two of studied factors on fruit lycopene content was, significant, in both seasons. Regarding the interaction between termination of cold storage $\times$ preharvest calcium chloride or potassium thiosulfate at $0.4 \%$ was, significantly, higher in fruit lycopene content than other combined treatments, in both years. Concerning the influence of interaction between of both pre-harvest foliar calcium chloride $\times$ potassium thiosulfate at $0.4 \%$ was, truly, higher in fruit lycopene content than other combined treatments, in two experimental seasons.

The $2^{\text {nd }}$ interaction among three factors under study on fruit lycopene content was significant, in both tested seasons. The combined treatment at termination of cold storage + pre-harvest foliar calcium chloride or potassium thiosulfate at $0.4 \%$ was, truly, higher value than values other combined treatments, in both seasons.

The stimulative influence on fruit lycopene content at termination than beginning of cold storage may be arise due to degradation of chlorophyll and increase the synthesis of lycopene which comprising $80-90 \%$ of carotenoids [31] [32]. Similar result has been reported by [23].

The positive effect of pre-harvest foliar application of calcium chloride on fruit lycopene content at termination of cold storage can be attributed to numerous factors like environment conditions and genotype, which can increase the biosynthesis of carotenoid [33]; [34]). The aforementioned result was in parallel to the results obtained by [10], [22] and [24] who elucidated that, foliar application of tomato plants with 10 and $15 \mathrm{mM} \mathrm{Ca}$, significantly, resulted in higher fruit lycopene content compared to the check treatment. 
The synergistic effect of pre-harvest foliar application of potassium thiosulfate on fruit lycopene content during cold storage was in accordance with [21] and [27] who mentioned that, exogenous application of potassium in tomato plants $\mathrm{cv}$. Nagina at $0.6 \%$ and $\mathrm{cv}$. Roma at $0.7 \%$ reflected maximum fruit lycopene content. On the other extreme, fruits lycopene content of tomato did not show any appropriate effect whether exogenous application of potassium was at 6 or $8 \mathrm{mM}$ compared to control treatment [24].

The improving effect of $1^{\text {st }}$ order interaction between termination of cold storage and preharvest foliar calcium chloride or potassium thiosulfate at $0.4 \%$ on fruit lycopene content can be discussed on the basis that, As an average of the two seasons, at the termination of cold storage; exogenous application of tomato plants at $0.4 \%$ calcium chloride surpassed over $0.2 \%$ and untreated control by 4.42 and $9.82 \%$ and pre-harvest foliar application of potassium thiosulfate at $0.4 \%$ augmented in comparison with $0.2 \%$ and control by 11.29 and $19.24 \%$, respectively. According to a positive results of the main effect of pre-harvest spraying of calcium chloride and potassium thiosulfate at $0.4 \%$ on fruit lycopene content consequently, the combined treatment of both; calcium chloride and potassium thiosulfate at $0.4 \%$ logically recorded the best of fruit lycopene content during cold storage.

The enhancing effect of the $2^{\text {nd }}$ order interaction among three studied factors on fruit lycopene content can be discussed on the current results; as an averaged of the two seasons, the combined treatment at termination of cold storage + pre-harvest foliar calcium chloride at $0.4 \%+$ potassium thiosulfate at $0.4 \%$ achieved the highest fruit lycopene content compared to untreated treatment by $29.80 \%$.

Table 5. Main and interaction effects of time in cold storage, pre-harvest foliar application of calcium chloride and potassium thiosulfate on fruit lycopene ( $\mathrm{mg} \mathrm{g}^{-1}$ fruit) content during 2014 and 2015 seasons

\begin{tabular}{|c|c|c|c|c|c|c|c|c|c|}
\hline \multirow{3}{*}{ Time } & \multirow{3}{*}{$\begin{array}{l}\text { Seasons } \\
\text { Calcium } \\
\text { chloride } \\
(\%)\end{array}$} & \multirow{2}{*}{\multicolumn{3}{|c|}{$\begin{array}{c}2014 \\
\begin{array}{c}\text { Potassium Thiosulfate } \\
(\%)\end{array}\end{array}$}} & \multirow{3}{*}{ Mean } & \multicolumn{3}{|c|}{2015} & \multirow{3}{*}{ Mean } \\
\hline & & & & & & \multicolumn{3}{|c|}{$\begin{array}{c}\text { Potassium Thiosulfate } \\
(\%)\end{array}$} & \\
\hline & & 0.0 & 0.2 & 0.4 & & 0.0 & 0.2 & 0.4 & \\
\hline \multirow{3}{*}{$\begin{array}{c}\text { 0 } \\
\text { Day }\end{array}$} & 0.0 & $0.0009^{\mathrm{k}^{*}}$ & $0.0015^{j}$ & $0.0015^{\mathrm{j}}$ & $0.0013^{f}$ & $0.0008^{\mathrm{g}}$ & $0.0008^{\mathrm{g}}$ & $0.0011^{g}$ & $0.0009^{\mathrm{d}}$ \\
\hline & 0.2 & $0.0021^{\mathrm{i}}$ & $0.0020^{\mathrm{i}}$ & $0.0018^{\mathrm{ij}}$ & $0.0019^{\mathrm{e}}$ & $0.0010^{\mathrm{g}}$ & $0.0010^{\mathrm{g}}$ & $0.0011^{\mathrm{g}}$ & $0.0011^{\mathrm{d}}$ \\
\hline & 0.4 & $0.0017^{\mathrm{i}}$ & $0.0019^{\mathrm{ij}}$ & $0.0029^{h}$ & $0.0022^{\mathrm{d}}$ & $0.0011^{\mathrm{g}}$ & $0.0010^{\mathrm{g}}$ & $0.0011^{\mathrm{g}}$ & $0.0011^{\mathrm{d}}$ \\
\hline \multirow{3}{*}{$\begin{array}{c}28 \\
\text { Day }\end{array}$} & 0.0 & $0.0173^{\mathrm{g}}$ & $0.0191^{\mathrm{e}}$ & $0.0210^{\text {cd }}$ & $0.0191^{c}$ & $0.0176^{f}$ & $0.0194^{\mathrm{d}}$ & $0.0218^{b}$ & $0.0196^{\mathrm{c}}$ \\
\hline & 0.2 & $0.0183^{f}$ & $0.0205^{\mathrm{d}}$ & $0.0218^{b}$ & $0.0202^{\mathrm{b}}$ & $0.0184^{\mathrm{e}}$ & $0.0210^{c}$ & $0.0220^{\mathrm{b}}$ & $0.0205^{\mathrm{b}}$ \\
\hline & 0.4 & $0.0193^{\mathrm{e}}$ & $0.0211^{\mathrm{c}}$ & $0.0225^{a}$ & $0.0210^{\mathrm{a}}$ & $0.0197^{\mathrm{d}}$ & $0.0219^{b}$ & $0.0228^{\mathrm{a}}$ & $0.0215^{\mathrm{a}}$ \\
\hline 0 day & & $0.0016^{\mathrm{f}}$ & $0.0018^{\mathrm{e}}$ & $0.0021^{\mathrm{d}}$ & $0.0018^{\mathrm{B}}$ & $0.0010^{\text {de }}$ & $0.0009^{\mathrm{e}}$ & $0.0011^{\mathrm{d}}$ & $0.0010^{\mathrm{B}}$ \\
\hline \multirow[t]{4}{*}{$\begin{array}{c}28 \\
\text { day }\end{array}$} & & $0.0183^{\mathrm{c}}$ & $0.0202^{\mathrm{b}}$ & $0.0218^{a}$ & $0.0201^{\mathrm{A}}$ & $0.0186^{c}$ & $0.0208^{\mathrm{b}}$ & $0.0222^{\mathrm{a}}$ & $0.0205^{\mathrm{A}}$ \\
\hline & 0.0 & $0.0091^{\mathrm{e}}$ & $0.0103^{d}$ & $0.0113^{\mathrm{c}}$ & $0.0102^{\mathrm{C}}$ & $0.0092^{g}$ & $0.0101^{\mathrm{e}}$ & $0.0114^{\mathrm{b}}$ & $0.0102^{\mathrm{C}}$ \\
\hline & 0.2 & $0.0102^{d}$ & $0.0113^{c}$ & $0.0118^{b}$ & $0.0111^{\mathrm{B}}$ & $0.0097^{\mathrm{f}}$ & $0.0110^{\mathrm{c}}$ & $0.0116^{\mathrm{b}}$ & $0.0108^{\mathrm{B}}$ \\
\hline & 0.4 & $0.0105^{\mathrm{d}}$ & $0.0115^{c}$ & $0.0127^{\mathrm{a}}$ & $0.0116^{\mathrm{A}}$ & $0.0104^{d}$ & $0.0115^{\mathrm{b}}$ & $0.0120^{\mathrm{a}}$ & $0.0113^{\mathrm{A}}$ \\
\hline Mean & & $0.0099^{\mathrm{C}}$ & $0.0110^{\mathrm{B}}$ & $0.0119^{\mathrm{A}}$ & & $0.0098^{\mathrm{C}}$ & $0.0109^{\mathrm{B}}$ & $0.0117^{\mathrm{A}}$ & \\
\hline
\end{tabular}

*Values marked with the same letter(s) within the main and interaction effects are statically similar using Revised LSD. Test at probability $=0.05$. Uppercase letter(s) indicate differences between main effects whilst, lowercase letter(s) refer to differences between interaction. 


\section{Fruit firmness}

The results in Table 6 illustrate the main and interactions impact of the three studied factors on fruit firmness content, in both experimental seasons.

Fruit firmness content was, significantly, lower at termination than beginning of cold storage period, in both seasons. Pre-harvest foliar application of calcium chloride at $0.4 \%$, significantly, produced more firm fruits than the untreated control during storage period, in both seasons. Preharvest tomato plants with potassium thiosulfate at $0.4 \%$ was, truly, higher in fruit firmness than other concentrations during cold storage, in both seasons except the difference between foliar potassium thiosulfate at $0.4 \%$ and control was not significant, in 2014 season.

The effect of $1^{\text {st }}$ interactions between any two studied factors under study was true, in both years. Concerning the termination of cold storage, pre-harvest calcium chloride at 0.2 and/or $0.4 \%$ was, significantly, more fruit firmness than other treatments, in both seasons. As for the termination of cold storage, pre-harvest potassium thiosulfate at $0.4 \%$ was, significantly, higher in fruit firmness than other combined treatments, in both years. Concerning the influence of interaction between preharvest foliar calcium chloride at 0.4 and/or $0.2 \% \times$ potassium thiosulfate at $0.4 \%$ was, truly, higher in fruit firmness than other combined treatments, in two experimental seasons.

The $2^{\text {nd }}$ interaction among three factors under study on fruit firmness was significant, in the both seasons. At termination of cold storage, pre-harvest foliar calcium chloride at 2 and/or $4 \%+$ potassium thiosulfate at $4 \%$ was, truly, the highest mean value in fruit lycopene, in both seasons.

The beneficial effect of pre-harvest calcium chloride at $0.4 \%$ on fruit firmness during cold storage can be discussed on the ground that, calcium appears to be involved in maintaining firmness due to its role as a major component of pectin's and in strengthening cell wall and membrane structure [35][36]. Calcium application usually leads to an increase in tissues calcium concentration that may affect the structure and functions of cell walls and membranes and cell metabolism events [37]. Calcium ions bind tightly to the pectin's in the cell walls and produce cationic bridges between pectic acids or between pectic acids and other acidic polysaccharides. These bridges make the cell walls less accessible to the action of pectolytic enzymes [38] [39]. A positive correlation between fruit firmness and its response to calcium treatment has been observed by [37]. Preliminary greenhouse studies have indicated that supplemental calcium chloride can improve onion bulb firmness [40].

The desirable impact of foliar pre-harvest potassium thiosulfate at $0.4 \%$ on fruit firmness during cold storage can be discussed on the basis of results [41] who indicated potassium nutrition had a positive influence on fruit firmness compared to untreated control. Some researchers as [42] and [43] have reported that $\mathrm{K}$ is the most important nutrient with regard to fruit firmness content.

According to a positive result of the main effect of foliar pre-harvest calcium chloride and potassium thiosulfate at $0.4 \%$ on fruit firmness during cold storage therefore, the combined treatment for calcium chloride and potassium thiosulfate at $0.4 \%$ together was additive and recorded the, significantly, highest mean value of fruit firmness, in both seasons. 
Table 6. Main and interaction effects of time in cold storage, pre-harvest foliar application of calcium chloride and potassium thiosulfate on fruit firmness $\left(\mathrm{kg} \mathrm{cm}^{-2}\right)$ content during 2014 and 2015 seasons

\begin{tabular}{|c|c|c|c|c|c|c|c|c|c|}
\hline \multirow{3}{*}{ Time } & \multirow{3}{*}{$\begin{array}{c}\text { Seasons } \\
\text { Calcium } \\
\text { chloride } \\
(\%)\end{array}$} & \multicolumn{3}{|c|}{2014} & \multirow{3}{*}{ Mean } & \multicolumn{3}{|c|}{2015} & \multirow{3}{*}{ Mean } \\
\hline & & \multicolumn{3}{|c|}{$\begin{array}{c}\text { Potassium Thiosulfate } \\
(\%)\end{array}$} & & \multicolumn{3}{|c|}{$\begin{array}{c}\text { Potassium Thiosulfate } \\
\text { (\%) }\end{array}$} & \\
\hline & & 0.0 & 0.2 & 0.4 & & 0.0 & 0.2 & 0.4 & \\
\hline \multirow{3}{*}{$\begin{array}{c}\text { 0 } \\
\text { Day }\end{array}$} & 0.0 & $5.567^{\mathrm{b}-\mathrm{d} *}$ & $5.367^{\mathrm{b}-\mathrm{d}}$ & $5.267^{\mathrm{b}-\mathrm{d}}$ & $5.400^{b}$ & $6.63^{\mathrm{ab}}$ & $6.53^{\mathrm{a}-\mathrm{c}}$ & $6.23^{b-d}$ & $6.47^{\mathrm{a}}$ \\
\hline & 0.2 & $5.867^{\mathrm{b}}$ & $5.367^{\mathrm{b}-\mathrm{d}}$ & $4.967^{\mathrm{d}}$ & $5.400^{b}$ & $6.77^{\mathrm{ab}}$ & $6.63^{\mathrm{ab}}$ & $6.37^{\mathrm{a}-\mathrm{c}}$ & $6.59^{\mathrm{a}}$ \\
\hline & 0.4 & $6.767^{\mathrm{a}}$ & $5.633^{\mathrm{bc}}$ & $5.433^{b-d}$ & $5.944^{\mathrm{a}}$ & $7.87^{\mathrm{a}}$ & $6.73^{a b}$ & $6.57^{\mathrm{a}-\mathrm{c}}$ & $7.06^{\mathrm{a}}$ \\
\hline \multirow{3}{*}{$\begin{array}{c}28 \\
\text { Day }\end{array}$} & 0.0 & $2.233^{i}$ & $2.900^{\text {gh }}$ & $2.767^{\mathrm{hi}}$ & $2.633^{\mathrm{e}}$ & $2.03^{\mathrm{g}}$ & $2.90^{\mathrm{fg}}$ & $4.70^{\mathrm{de}}$ & $3.21^{\mathrm{c}}$ \\
\hline & 0.2 & $2.667^{\mathrm{hi}}$ & $3.133^{\mathrm{f}-\mathrm{h}}$ & $3.967^{\mathrm{e}}$ & $3.256^{\mathrm{d}}$ & $3.73^{\mathrm{ef}}$ & $3.60^{\mathrm{e}-\mathrm{g}}$ & $7.63^{\mathrm{ab}}$ & $4.99^{\mathrm{b}}$ \\
\hline & 0.4 & $3.700^{\text {ef }}$ & $3.467^{\mathrm{e}-\mathrm{g}}$ & $5.167^{\mathrm{cd}}$ & $4.111^{\mathrm{c}}$ & $4.27^{\mathrm{ef}}$ & $4.30^{\mathrm{ef}}$ & $5.03^{\mathrm{c}-\mathrm{e}}$ & $4.53^{\mathrm{b}}$ \\
\hline 0 day & & $6.067^{\mathrm{a}}$ & $5.456^{\mathrm{b}}$ & $5.222^{b}$ & $5.581^{\mathrm{A}}$ & $7.09^{\mathrm{a}}$ & $6.63^{\mathrm{ab}}$ & $6.39^{\mathrm{ab}}$ & $6.70^{\mathrm{A}}$ \\
\hline \multirow[t]{4}{*}{28 day } & & $2.867^{\mathrm{d}}$ & $3.167^{\mathrm{d}}$ & $3.967^{\mathrm{c}}$ & $3.333^{\mathrm{B}}$ & $3.34^{\mathrm{c}}$ & $3.60^{\mathrm{c}}$ & $5.79^{\mathrm{b}}$ & $4.24^{\mathrm{B}}$ \\
\hline & 0.0 & $3.900^{d}$ & $4.133^{\mathrm{b}-\mathrm{d}}$ & $4.017^{\mathrm{cd}}$ & $4.017^{\mathrm{B}}$ & $4.33^{d}$ & $4.72^{\mathrm{cd}}$ & $5.47^{b-d}$ & $4.84^{\mathrm{B}}$ \\
\hline & 0.2 & 4.267 bc & $4.250^{b-d}$ & 4.467 bc & $4.328^{\mathrm{B}}$ & $5.25^{\mathrm{b}-\mathrm{d}}$ & $5.12^{b-d}$ & $7.00^{\mathrm{a}}$ & $5.79^{\mathrm{A}}$ \\
\hline & 0.4 & $5.233^{\mathrm{a}}$ & $4.550^{\mathrm{b}}$ & $5.300^{\mathrm{a}}$ & $5.028^{\mathrm{A}}$ & $6.07^{\mathrm{ab}}$ & $5.52 \mathrm{bc}$ & $5.80^{\mathrm{bc}}$ & $5.79^{\mathrm{A}}$ \\
\hline Mean & & $4.467^{\mathrm{AB}}$ & $4.311^{\mathrm{B}}$ & $4.594^{\mathrm{A}}$ & & $5.22^{\mathrm{B}}$ & $5.12^{\mathrm{B}}$ & $6.09^{\mathrm{A}}$ & \\
\hline
\end{tabular}

${ }^{*}$ Values marked with the same letter(s) within the main and interaction effects are statically similar using Revised LSD. Test at probability $=0.05$. Uppercase letter(s) indicate differences between main effects whilst, lowercase letter(s) refer to differences between interaction.

\section{Conclusions}

Results of the current study indicate that foliar application of the integrated treatment of calcium chloride $\times$ potassium thiosulfate at $0.4 \%$ for both to tomato plants was distinguished and increased fruit quality; tomato fruit titratable acidity, vitamin $\mathrm{C}$ and lycopene contents at the end of cold storage. Compared to other treatments, therefore, the interaction of cold storage at $10 \pm 2{ }^{\circ} \mathrm{C}$ for 28 days (with relative humidity of $90 \%$ ) $\times$ calcium chloride at $0.4 \% \times$ potassium thiosulfate at $0.4 \%$ was the best treatment that improved tomato fruit quality, which we recommend to use contributing to agriculture sustainability.

\section{References}

[1] Rick, C. M. 1978. The tomato. Scientific American, 239: 76 - 87.

[2] Agriculture organization of the united nations statistics division. Available at: http://faostat3.fao.org/browse/Q/QC/E.

[3] USDA. 2016. United States Department of Agriculture, National Nutrient Database for Standard Reference Release 28 (Basic Report: 11529). Agric. Res. Service. Available at: https://ndb.nal.usda.gov/ndb/foods/show/3223? fgcd=\&manu=\&lfacet=\&format $=\&$ count $=\&$ max $=35$ \&offset=\&sort=\&qlookup=11529.

[4] Bonte-Friedheim, C. H. 1989. Prevention of postharvest food losses: fruits, vegetables and root crops. FAO Training Series, (17/2).

[5] Coursey, D. G. 1983. Post- harvest losses in perishable foods of the developing world. In PostHarvest Physiology and Crop Preservation (pp. 485 - 514). Springer US. 
[6] Bourne, M. 1986. Overview of postharvest problems in fruits and vegetables. Postharvest Food Losses in Fruits and Vegetables: 1 - 16: National Academy Press, Washinton, DC.

[7] Dorais, M., A. P. Papadoulos and A. Gosselin. 2001. Greenhouse tomato fruit quality. In: Janick, J. (Ed.), Hort. Review. 26: 319-239.

[8] Pretorious, J. C., E. Van der Watt and R. A. Buitendag. 2003. Natural products from plants. Dept. soil, crop and climate Sci., Univ. Free State, PO Box 339, Bloemfontein.

[9] Fischer, A. D. A. and C. Richter. 1986. Influence of organic and mineral fertilizers on yield and quality of potatoes. In: Importance of biological agriculture: in a world of diminishing resources, Vogtmann, H., E. Boehncke and I. Fricke (Eds.). Proc. 5th IFOAM Inter. Scientific Conf. Univ. of Kassel (Germany), Aug. 27 - 30.

[10] Subbiah, K. and R. Perumal. 1990. Effect of calcium sources, concentrations, stages and number of sprays on physio-chemical properties of tomato fruits. South Indi. Hort. 38(1): 20 - 27.

[11] Abd-El-Rahman, M. E. 2003. Effect of nitrogen and potassium fertilization on growth, flowering, yield potential and fruits quality of two tomato hybrids. M.Sc. Thesis, Fac. Agric., Cairo Univ.

[12] Kader, A. A. and R. S. Rolle. 2004. The role of post-harvest management in assuring the quality and safety of horticultural produce. Food and Agric. Org. 152.

[13] Wilde, S. A., R. B. Corey, J. G. Lyer and G. K. Voight. 1985. Soil and Plant Analysis for Tree culture. Oxford and IBM Publishers. New Delhi. India. $3^{\text {rd }}$ ed. $93-106$ pp.

[14] Srivastava, R. P. and S. Kumar. 2015. Fruit and vegetable preservation: principles and practices: CBS Publishers and Distributors Pvt. Limited.

[15] Perkins-Veazie, P., J. K. Collins, S. D. Pair and W. Roberts. 2001. Lycopene content differs among red-fleshed watermelon cultivars. J. Sci. Food and Agric. 81(10): 983 - 987.

[16] Al-Rawi, K. M. and A. M. Kalf-Allah. 1980. Design and analysis of Agriculture Experiments. El-Mousl Univ., Iraq,19, 487.p.

[17] Genanew, T. 2013. Effect of post-harvest treatment on storage behavior and quality of tomato fruit. World J. Agric. Sci. 9(1): 29 - 37.

[18] Opiyo, A. M. and T. J. Ying. 2005. The effect of 1- methylcyclopropene treatment on the shelf life and quality of cherry tomato (Lycopersicon esculentum var. cerasiforme) fruit. Inter. J. Food Sci. and Technol. 40(6): 665 - 673.

[19] Mujtaba, A., T. Masud, S. J. Butt, M. A. Qazalbash, W. Fareed and A. Shahid. 2014. Potential role of calcium chloride, potassium permanganate and boric acid on quality maintenance of tomato cv. Rio grandi at ambient temperature. Inter. J. Bio-Sci. 5 (9): $9-20$.

[20] El-Badawy, H. E. M. 2012. Effect of chitosan and calcium chloride spraying on fruits quality of florida prince peach under cold Storage. Res. J. Agric. Biol. Sci. 8(2): 272 - 281.

[21] Amjad, M., J. Akhtar, M. A. Ul-HAQ, S. Imran and S. Jacobsen. 2014. Soil and foliar application of potassium enhances fruit yield and quality of tomato under salinity. Turk. J. Biol. 38: 208 - 218.

[22] Abbasi, N. A., L. Zafar, H. A. Khan and A. A. Quresh. 2013. Effects of naphthalene acetic acid application on nutrient uptake, growth, yield and postharvest performance of tomato fruit. Pak. J. Bot. 45(5): 1581-1587.

[23] Gharezi, M., N. Joshi and E. Sadeghian. 2012. Effect of postharvest treatment on stored cherry tomatoes. J. Nutri. Food Sci. 2: 157 - 66.

[24] Kazemi, M. 2014 Effect of foliar application of humic acid and calcium chloride on tomato growth. Bull. Env. Pharmacol. Life Sci. 3 (3): 41 - 46. 
[25] Anac, D. and H. Colakoglu. 1993. Response of some major crops to K fertilization. In: Proc. Regional symposium on K availability of soils in West Asia and North Africa 235-247. June 19 - 22, 1993, Tehran, Iran.

[26] Ibrahim, F. M., G. Abd El-Gawad and M. Bondok. 2015. Physiological impacts of potassium citrate and folic acid on growth, yield and some viral diseases of potato. Plants Middle East J. Agric. 4 (3): $577-589$.

[27] Afzal, I., B. Hussain, S. M. A. Basra, S. H. Ullah, Q. Shakeel and M. Kamran. 2015. Foliar application of potassium improves fruit quality and yield of tomato plants. Acta Scientiarum Polonorum., Hortorum Cultus, 14(1):12 -18.

[28] Rab, A. and I. Haq. 2012. Foliar application of calcium chloride and borax influences plant growth, yield and quality of tomato (Lycopersicon esculentum Mill.) fruit. Turki. J. Agric and Foresty, 36(6): $695-701$.

[29] Akhtar, M. E., M. Z. Khan, M. T. Rashid, Z. Ahsan and S. Ahmad. 2010. Effect of potash application on yield and quality of tomato (Lycopersicon esculantum Mill.) Pak. J. Bot. 42 (3): 1695 $-1702$.

[30] Chapagain, B. P. and Z. Wiesman. 2004. Effect of Nutri-Vant-PeaK foliar spray on plant development, yield and fruit quality in greenhouse tomatoes. Scientia Hort. 102: 177 - 188.

[31] Agarwal, S. and A. V. Rao. 1998. Tomato lycopene and low density lipoprotein oxidation: a human dietary intervention study. Lipids 33: 981- 984.

[32] Yadav, R. K, S. K. Sanwal, P. K. Singh and B. Juri. 2009. Effect of pretreatments and packaging of tomato in LDPE and PET films on the storage-life. J. Food Sci. Technol. 46: 139 - 141.

[33] Toor, R. K and G. P. Savage. 2005. Antioxidant activity in different fractions of tomatoes. Inter. Food Res. J. 38: 487 -494.

[34] George, B., C. Kaura, D. S. Khurdiya and H. C. Kapoor. 2004. Antioxidant in tomato (Lycopersicon esculentum) as a function of genotype. Food Chem. 84: 45 - 51.

[35] Maas, J. L. 1998. Compendium of strawberry diseases. St. Paul, Minnesota, USA, APS Press.

[36] Sams, C. E. 1999. Pre-harvest factors affecting postharvest texture. Postharvest Biol. and Techno. 15(3): $249-254$.

[37] Chéour, F., C. Willemot, J. Arul, J. Makhlouf and Y. Desjardins. 1991. Post-harvest response of two strawberry cultivars to foliar application of $\mathrm{CaCl}_{2}$. HortScience. 26: 1186-1189.

[38] Moline, H. E. 1994. Pre-harvest management for postharvest biological control. In: Biological Control of Postharvest Diseases - Theory and Practice. C. L. Wilson and M. E. Wisniewski (Eds.). CRC Press, Boca Raton, Florida, USA, $57-62$.

[39] Conway, W. S., C. E. Sams, C.Y.Wang and J. A. Abbott. 1994. Additive effects of postharvest calcium and heat treatment on reducing decay and maintaining quality in apples. J. Amer. Soc. Hort. Sci.119(1): 49 - 53.

[40] Coolong, T. W. and W. M. Randle. 2008. The effects of calcium chloride and ammonium sulfate on onion bulb quality at harvest and during Storage. HortScience 43(2): $465-471$.

[41] Brüning, D. 1976. Befall with Eulecanium corni Bshe. F. robinarium Dgl. with Eulecanium rufulum Ck1l. into fertilization experiments to deciduous wood. Plant Protection J. 3: 193 - 200.

[42] Smith, G. S., C. J. Clark and J. G. Buwalda. 1985. K deficiency of kiwi fruit. Proc. R Hort. Conf. p. 13 - 16.

[43] Smith, G. S. and C. J. Clark. 1984. No boron, but plenty of potash. New Zealand Kiwi fruit J. 8: 18 . 